\title{
FEDERAL WORKMEN'S COMPENSATION FOR TRANSPORTATION EMPLOYEES
}

\section{WALTER GELLHORN $\dagger$}

OvER twenty years ago a special commission of Congress, presided over by Senator, now Justice, George Sutherland, advocated the adoption of a workmen's compensation law applicable to employees of interstate railroads. ${ }^{1}$ Both Houses of Congress voted favorably on a proposal to carry out the commission's recommendation; but minor disagreements in details of the measure as adopted in the two Houses were seized upon to foreclose passage of an act during that Congress, ${ }^{2}$ and the favorable moment passed. Workmen's compensation for the railroads was sidetracked.

The defeat then inflicted, engineered in large measure by lawyers who refused to surrender the rich fee-bearing lode of personal injury cases arising out of railroading, ${ }^{3}$ might well have been viewed as a fatal wound to the movement for a compensation act. And so perhaps it would have been, had the substitute retained by Congress functioned with even a fair degree of satisfaction. But the Federal Employers' Liability Act has proved a failure, and recent efforts to improve it have made no headway. ${ }^{4}$ The proposal for workmen's compensation again comes to the fore as offering the most effective solution of the problem.

In the furtherance of this proposal, Senator Wagner of New York will soon introduce in Congress a bill providing for a workmen's compensation scheme..$^{5}$ Included within its terms, by Section $2(3)$, are all employers

$\dagger$ Assistant Professor of Law, Columbia University.

1. Report of Commission to Investigate the Matter of Enployers' Liability and Workmen's Compensation, Sen. Doc. No. 338, 62d Cong., 2d Sess. (1912) Ser. No. 6151. This report will hereafter be referred to as the Sutherland Commission Report.

2. The Senate, following a favorable report, SEN. REP. No. 553, 62d Cong., 2d Sess. (1912) Ser. No. 6121, voted favorably on the bill (S. 5382) on May 6, 1912. (1912) 48 Conc. REc. 5959. The House Committee reported the bill favorably with amendments, and on March 1, 1913, the House adopted the Senate Bill as amended. (1913) 49 Cong. Rec. 4547. Obstructionistic tactics in the Senate prevented action on Senator Sutherland's motion that the Senate concur in the House amendments. See (1913) 49 Cong. Rec. $4562-4563,4673-4675,4676-4677$.

3. Clark, Workmen's Compensation and the Railroads: $A$ Hesitating Revolution (1933) 41 J. Por. Econ. 806, 807-809.

4. H. R. 10425, H. R. 11181, H. R. 11182, H. R. 11498, 72d Cong, 1st Sess. (1932). See remarks on two of these bills in 75 CoNG. REc. 12362-12363 (1932).

5. This bill has been prepared for Senator Wagner by the American Association for Labor Legislation, in conjunction with the Legislative Drafting Research Fund of the Columbia Law School. The Association has been a consistently active proponent of the compensation principle. 
"engaged in interstate or foreign commerce as:

(1) A common carrier by railroad; or

(2) An express company or sleeping car or dining car company; or

(3) A pipeline company; or

(4) A common or contract carrier by air craft or any vehicle in commerce between fixed termini or on a regular schedule or route."

Unlike earlier drafts introduced by Senator Wagner at recent sessions of Congress, ${ }^{6}$ the new bill brings within the scope of the compensation plan practically all employees of these different types of interstate carriers. Section 3(a) provides that compensation shall be payable in respect of disability or death of an employee incurred when he "is in the service of an employer subject to this Act and is engaged:

(1) in transportation service; or

(2) in duties in or upon any agency or means of transportation; or

(3) in the operation, protection, construction, maintenance, repair, moving, or inspection of any agency or means of transportation or of any structure, track, right of way, road, field, equipment, appliance, or appurtenance used or useful in connection with transportation."7

The bill as a whole is modelled upon the Longshoremen's and Harbor Workers' Compensation Act, ${ }^{s}$ with such refinements as experience has shown to be wise or as differences between the types of employments necessitate. The section likely to be the most controversial from the standpoint of its constitutionality is Section 3(a). By its terms employees are to be included within the protection of the compensation law without reference to whether their activity is in interstate or intrastate commerce or transportation at the time of their injury; the application of the proposed statute will be conditioned upon the type of service performed, rather than upon the interstate character of the employment. Upon the validity of that classification much of the value of the proposal depends. ${ }^{9}$

6. S. 1320, 73d Cong., 1st Sess. (1933); S. 5695, 72d Cong., 2d Sess. (1933); S. 4927, 72d Cong., 1st Sess. (1932). An earlier bill, introduced by Representative LaGuardia, had sought to provide workmen's compensation as to certain employments in interstate and foreign air commerce. H. R. 141, 71st Cong., 1st Sess. (1929).

7. Section 3 (b) specifically excludes from the operation of the act (1) masters or members of a crew of any vessel, (2) employees of any government, (3) persons entitled to compensation under the Longshoremen's and Harbor Workers' or the District of Columbia compensation acts.

8. Act of March 4, 1927, c. 509, 44 Star. 1424 (1927), 33 U. S. C. Supp. VII, $\$ \S 901-950$ (1933), as amended by the Act of May 4, 1928, c. 502, 45 StaT. 490 (1928), 33 U. S. C. Supp. VII $\$ 921$ (a) (1933).

9. See Richberg, Workmen's Compensation for Railway Entployees (1933) 23 Aar. LAB. LEG. REv. 51, 52, where Mr. Donald Richberg, a warm friend of the compensation principle, expresses a possible doubt concerning the desirability of a federal law applicable only to those injured while engaged in interstate transportation. 
The history of the Federal Employers' Liability Act is familiar. The first $\mathrm{Act}^{10}$ provided that every common carrier operating in interstate commerce should be liable "to any of its employees" for damages resulting from its negligence. This provision the Supreme Court declared unconstitutional in The Employers Liability Cases, ${ }^{11}$ on the ground that it embraced employees in intrastate commerce and hence constituted an unwarranted extension of federal regulation. The second Act, ${ }^{12}$ drafted to escape the fate of its predecessor, applied only to railroads in interstate, territorial, or foreign commerce and extended only to such employees of the carrier as suffered injury while they were employed "in such commerce." Thus restricted, it was triumphantly upheld by the Supreme Court in Mondou v. Nere York, New Haven \& Hartford $R r . C o .,{ }^{13}$ and so launched upon a career marked by ceaseless litigation, endless and inconclusive "interpretation," and failure to fulfill the desired objective of protecting workmen in an especially hazardous occupation.

The decisions in cases arising under the Federal Employers' Liability Act have shown the extreme difficulty of determining whether or not an employee was engaged in interstate commerce at the time he was injured. ${ }^{14}$ Indeed, the Court itself, through $\mathrm{Mr}$. Justice McKenna, has explicitly recognized and articulated the impossibility of establishing any effective criterion for determining whether a case falls within the terms of the Act. ${ }^{15}$ This uncertainty results not only in an overcrowding of the dockets of appellate courts ${ }^{16}$ with a type of case that yields no contribution to the progress of the law $;^{17}$ it may also operate to

10. 34 STAT. 232 (1906).

11. 207 U. S. 463 (1908).

12. Act of April 22, 1908, c. 149, 35 STaT. 65 (1908), 45 U. S. C. $\$ \$ 51-59$ (1926).

13. 223 U. S. 1 (1912).

14. See an excellent review of the cases in Schoene and Watson, Workmen's Compensation on Interstate Railways (1934) 47 HARv. L. REv. 389, 399-407; and see Note (1933) 13 B. U. L. REv. 329. Examination of cases in the lower federal courts and in the appellate courts of the states reveals the same bewildering confusion that is observed in the Supreme Court holdings.

15. See Industrial Accident Commission v. Davis, 259 U. S. 182, 188 (1922).

16. See Frankfurter and Landis, THe Business of THE Supreare Court (1927) 206 et seg.; and see Message of President Taft, Sutherland Commission Report, supra note 1, at 8 .

17. For an especially trenchant demonstration that "the Supreme Court cultivates sterile soil in this field of litigation," see Frankfurter and Landis, The Business of the Supreme Court at October Term, 1931 (1932) 46 HARv. L. Rev. 226, 240-253. Note particularly the authors' conclusion that "The deepest significance of these cases is the proof they furnish of the futility of the Act itself. When the process of interpretalion and 
deprive an injured workman of any recovery, by reason of his having chosen the wrong forum in which to press his claim. ${ }^{18}$

Even if the case is clearly one falling within the Act, the injured employee, or the representatives of one who was killed in the course of his employment, may have no assurance of success. Although the negligence of the employer must be clearly established as in an ordinary tort action, ${ }^{19}$ the Act purports to abolish the defenses of contributory negligence and the fellow-servant rule. Yet the consequence of Supreme Court decisions ${ }^{20}$ has been to resurrect them in the guise of a vibrant application of the assumption of risk doctrine, and thus effectually to remove the supposed safeguards against use of the common-law defenses. ${ }^{21}$ The real fruit of the Supreme Court's interpretation of the Act has been a recognition by the employer of the value of prolonging litigation in a situation in which prompt settlement is typically essential to prevent destitution and suffering among members of a class deprived of their earning capacity and hence peculiarly likely to become public charges. The road to final adjudication, it has recently been observed, ${ }^{22}$ has been "made longer and more expensive than it was before the Act,

application after twenty-five years still yields unabated litigation and reveals an apparent growing inability upon the part of judges primarily intrusted with its administration to know its meaning, surely the legislation has proven a failure." Id. at 249.

18. See Schneider, Federal Employers' Liability Act, Workmen's Compensation Act, or Common Law-IVhich? (1922) 95 CENT. L. J. 118; Albertsworth and Cilella, A Proposed "New Deal" for Interstate Railway Industrial Harms (1934) 28 IrI. L. REv. 587, 598-600; Richberg, sutpra note 9. Compare Moore v. Chesapeake \& Ohio Ry. Co., 54 Sup. Ct. 402 (1934), where, in the first paragraph of the complaint, plaintiff alleged that at the time of injury he was employed in interstate commerce, and, in the second paragraph, that at the time of injury he was employed in intrastate commerce.

19. See Pennsylvania Rr. Co. v. Chamberlain, 288 U. S. 333 (1933).

20. See, e.g., Toledo, St. Louis, and Western Rr. Co. v. Allen, 276 U. S. 165 (1928); and see Northwestern Pacific Rr. Co. v. Bobo, 290 U. S. 499 (1934); Bernola v. Pennsylvania Rr. Co., 68 F. (2d) 172 (C. C. A. 3d, 1933); Blackley v. Powell, 68 F. (2d) 457 (C. C. A. 4th, 1934).

21. See Comment (1932) 42 Yale L. J. 226; Note (1932) 32 Col. L. Rev. 1384; Albertsworth and Cilella, supra note 18, at 591-595; Welman, Assumed Risk under the Federal Employers' Liability Act (1928) 3 IND. L. J. 365; Peterson, The Joker in the Federal Employers' Liability Act (1915) 80 CENT. L. J. 5; cf. Aronson, Federal Employers Liability Act (1932) 2 BRkLnN. L. Rev. 37. New hazards of railroading, not within the scope of safety appliances acts, such as the severe jolting resulting from slack action of heavilyladen and excessively Jong freight trains, are frequent causes of injury [cf. Arguments for and Against Limitation of Length of Freight Trains (1916) Bur. of Ry. EcoN., Bull. No. 92] and are usually regarded as among the accepted risks of employment. See Richberg, Advantages of a Federal Compensation Act for Railway Employees (1931) 21 AMr. LAB. LEG. REV. 401, 402.

22. See Comment (1932) 42 Yale L. J. 226, 233; see also Schoene and Watson, supra note 14 , at $408-409$. 
with the added probability that should the employee's case reach the Supreme Court he will lose. These facts have furnished the railroads a powerful weapon by which they may force disadvantageous settlements from their employees." 23

To the above criticisms of the functioning of the Federal Employers' Liability Act may be added the further charge that recoveries are inadequate to compensate employees for their losses. While it is undoubtedly true that large verdicts or settlements are frequently obtained in death and serious injury cases, the fact is that, wholly apart from cases in which there is failure of proof of the right to recovery, ${ }^{24}$ the mass of claimants receive less than the amount that would have been theirs under a compensation award. ${ }^{25}$ Lawyers' fees and expenses of litigation consume much of what is recovered, and in many classes of injury the injured man must contemplate no recovery at all or a settle-

23. Recent cases in the Supreme Court attest to the long delays often experienced in this type of litigation. See, e.g., Chicago and Northwestern Ry. Co. v. Bolle, 284 U. S. 74 (1931) (nine years after injury, judgment entered in the Supreme Court dismissing plaintiff's suit); Baltimore and Ohio Rr. Co. v. Carroll, 280 U. S. 491 (1930) (thirteen year interval between commencement and termination of the action).

Under present conditions, moreover, there is no assurance that state workmen's compensation laws, where applicable to railroad employees, will be permitted to function with their accustomed celerity. In Chicago \& Eastern Illinois $\mathrm{Rr}$. Co. v. Industrial Commission, 284 U. S. 296 (1932), the judgment of the Supreme Court was rendered two years after the employee filed with the State Commission a claim for compensation. The facts of the injury were not in dispute; the delay was occasioned by the employer's insistence that the worker was employed in interstate commerce when injured. The Supreme Court finally rejected this contention.

24. See, e.g., Pennsylvania Rr. Co. v. Chamberlain, supra note 19; Atchison, Topeka \& Sante Fe Ry. Co. v. Saxon, 284 U. S. 458 (1932); New York, New Haven \& Hartford Rr. Co, v. Bezue, 284 U. S. 415 (1932).

25. Mr. L. F. Loree, president of the Delaware \& Hudson Railroad Corporation, contends that not only do injured employees and their dependents receive less than under compensation laws, but also that the railroads pay more than they should in justice be required to pay. See Loree, Railway Employer Favors Workmen's Compensation (1933) 23 Aar. Lab. Leg. Rev. 110. Cf. Sutherland Commission Report, supra note 1, at 23-24, 8586; and see Clark, supra note 3, at 809-810. Strong support for this view is found in a study of a strictly analogous situation undertaken by the Bureau of Labor Statistics. Seamen are excepted from the Longshoremen's and Harbor Workers' Compensation Act, though included in the bill as originally drawn. By the Act of June 5, 1920, c. 250, \$ 33, 41 Srat. 1007 (1920), 46 U. S. C. $\$ 688$ (1926), "all statutes of the United States modifying or extending the common-law right or remedy in cases of personal injury to railway employees," are made applicable in actions brought by seamen. A survey showed that injured seamen actually gained less and the employers paid more money than if the former had been compensated for injury on the basis of the schedules enacted by Congress in 1927 for other marine workers. See Settlement for Accidents to American Seamen (1928) U. S. BUR. OE LAB. Srat., Bull. 466; Id. (1928) 26 MoN. LaB. Rev. (No. 6) 6. And see Albertsworth and Cilella, supra note 18 , at 789 . 
ment dependent on the employer's largesse. ${ }^{26}$ The rules of many railroads provide that institution of suit against the company operates automatically to terminate the plaintiff's employment, and where the injury is relatively slight, fear of loss of employment as well as the cost of the suit prevents the bringing of an action. Since the congressional enactment bars recourse to state compensation laws, ${ }^{27}$ a large number of these industrial accidents result in direct burdens upon the community at large, rather than upon the industry in which they occurred.

\section{II}

The growing recognition that the Liability Act cannot function effectively in the field of interstate railroad injuries has provoked advocacy of appropriate remedial legislation. The late Chief Justice Taft gave vigorous expression to the need of a federal compensation law. ${ }^{28}$ More recently, two thoughtful studies of the problem have appeared, one discussing amendment within the framework of the existing Act ${ }^{29}$ and the other urging the repeal of the Act and the remission of the whole question to the individual states. ${ }^{30}$

The proposal for reform through amendment rather than by a wholly new approach to the problem may be summarily dismissed, for, as has been indicated, the operation of the Act has revealed its deficiencies as a remedial or protective measure. Retention of such a discredited legislative plan is certainly not necessitated by any constitutional re-

26. Cf. Hearings held before the Sutherland Commission, SEN. Doc. No. 338, 62d Cong., 2d Sess. (1912) Ser. No. 6152, at 1055-1056.

27. See New York Central Rr. Co. v. Winfield, 244 U. S. 147 (1917); cf. Boston \& Maine Rr. Co. v. Armburg, 285 U. S. 234 (1932), discussed at p. 912, infra.

28. See Address to the American Law Institute, May 9, 1929, published in (1929) 15 A. B. A. J. 332-333.

29. Albertsworth and Cilella, supra note 18. The authors do not, however, commit themselves to approval of retention of the tort basis of the Act. They mention, but do not necessarily advocate, attempted restriction of the defense of assumed risk in death cases; possible extension of the coverage of the Act; creation of a cause of action for occupational diseases; erection of a conclusive presumption that, where an employee is found deceased on the premises of the employer, the employee exercised due care and the rail employer was negligent; and a rule that assumed risk would not bar recovery, but merely diminish the damage recoverable.

In a second installment of their article, 28 Irr. L. REv. 774 (1934), the same authors consider and reject the possibility of returning to the states the power to legislate with reference to injuries suffered by railroad employees. They favor a "limited federal compensation act, restricted to the interstate acts of rail employees." Id. at 788 .

30. Schoene and Watson, supra note 14, at 411-422; cf. Richberg, supra note 9. H. R. 12170, 72d Cong., 1st Sess. (1932), provided that the Workmen's Compensation Law of any state might apply, within that state, to employments in interstate commerce. The measure was referred to the Committee on the Judiciary which never reported it out. 
requirement or prohibition. The alternatives are twofold: (1) Complete abdication of congressional control; (2) Formulation of a federal workmen's compensation plan devised, as is the bill under discussion, to avoid the defects of the present system. ${ }^{31}$

State control is subject to the disadvantage that four states, Arkansas, Florida, Mississippi, and South Carolina, have no compensation acts at all, that many other states provide ludicrously small benefits, and that numerous existing acts would require amendment or additions before being applicable to the employees now subject to the Federal Employers' Liability Act. ${ }^{32}$

Further serious obstacles may be suggested. It is not at all clear that the states could, without creating what would be held to constitute an unconstitutional burden upon interstate commerce, devise a practicable scheme for providing insurance for the workers on interstate railroads. Railroad workers may be and frequently are employed in more than one state. The deposit of securities or the posting of a bond or the purchase of insurance in each of the states, in an amount adequate to safeguard the maximum number of employees who might there be engaged in work at any given moment, might prove too onerous an expense. No decision of the Supreme Court has dissipated fear of that possibility. In Boston \& Maine Railroad Co. v. Armburg, ${ }^{23}$ it is true, it was held that the Massachusetts compensation law was valid, even though it required railroad companies to undertake the difficult task of computing the number of employees within that state who were not within the reach of the Federal Act. But the basis of Mr. Justice Stone's opinion is the same as that recently noted in cases arising under the due process clause, namely, that the party attacking the statute had failed to prove the facts upon which his attack was founded..$^{34}$ The decision does not foreclose consideration of the question on a more ample record. Moreover, whether constitutional or not, enforced compliance by interstate railroads with the diverse laws of all the states would prove burdensome in fact and might compel a readjustment of rates to cover the added expense.

31. Albertsworth and Cilella advocate the earlier Wagner plan, limited in its coverage much as is the present Liability Act. This plan would perpetuate the recurrent problem, already noted, of determining whether an employee was engaged in inter- or intrastate transportation when injured. That problem, with its implications of litigation, might well destroy the effectiveness of the compensation principle.

32. See and compare Schoene and Watson, supra note 14, at 411-422.

33. Supra note 27.

34. Id. at 240: ". . . it is not self-evident that the Act is unworkable, and there is nothing on the record which would enable us to say that such allocation is either impossible or so difficult as necessarily to impose any burden on interstate commerce. . . . There are 
Another substantial objection to relegating the accident compensation question to the states is found in the conflict of laws problems inherent in typical railroad employments. The resident of one state may make a contract for his services in a second and may proceed to perform that contract in half a dozen other states. Determination of what law governs when accidents occur in interstate movements may prove as difficult as has solution of the interstate-intrastate question raised by the Liability Act. ${ }^{35}$ An incentive to litigation of that question would remain so long as the compensation benefits of one state statute were greater than those obtainable under another ${ }^{36}$ Difficulties of the kind here indicated, however, might possibly be diminished by some type of congressional formulation of venue provisions, in the event state workmen's compensation acts were made applicable to all transportation employees. Similarly, Congress might consent to the burden on interstate commerce resulting from the application of diverse insurance requirements.

no findings and the petitioner asked no ruling with respect to the point. There is no evidence from which it could be inferred that the allocation could not be made or that insurance could not be effected at a cost bearing a fair relation to the intrastate service to which the Act applies. The burden was on petitioner, who assailed the statute, to establish its unconstitutionality. O'Gorman \& Young, Inc. v. Hartford Fire Ins. Co., 282 U. S. 251; Hardware Dealers Mutual Fire Ins. Co. v. Glidden Co., 284 U. S. 151, 158." Cf. Pacific Telephone \& Telegraph Co. v. Seattle, 54 Sup. Ct. 383 (1934).

35. Bradford Electric Light Co. v. Clapper, 286 U. S. 145 (1932), has by no means eliminated the problems springing from conflicting statutes. Cf. Schoene and Watson, supra note 14 , at 413 , n. 131. Compare with the Bradford Electric Co. case, Ohio v. Chattanooga Boiler \& Tank Co., 289 U. S. 439 (1933) ; and cf. Esau v. Smith Bros., 124 Neb. 217, 246 N. W. 230 (1933); Daggett v. Kansas City Structural Steel Co., 65 S. W. (2d) 1036 (Mo. 1933); and Migues' Case, 281 Mass. 373, 183 N. E. 847 (1933). See Dwan, Workmen's Compensation and the Confict of Laws (1927) 11 MinN. L. Rev. 329; Note (1933) 10 N. Y. U. L. Q. Rev. 518; Note (1932) 46 Harv. L. Rev. 291. See also Cameron v. Ellis Construction Co., 252 N. Y. 394, 169 N E. 622 (1930) ; Proper v. Poiley, 259 N. Y. 516, 182 N. E. 161 (1932), af'g 233 App. Div. 621, 253 N. Y. Supp. 530 (3d Dep't 1931), noted in (1932) 32 CoL. L. REv. 1427; Smith v. Aerovane Utilities Corp., 259 N. Y. 126, 181 N. E. 72 (1932), noted in (1933) 27 IlL. L. REv. 571.

36. While it is true that uniformity is not desirable per se in every type of social legislation, it would appear that much is to be said in its favor in the present connection. Elimination of the litigation suggested in the text would alone be strongly persuasive of the merits of a uniform rule. Likewise the consequences of the litigation may create a discontent that will continue long beyond the duration of the controversy. $C f$. Hearings, supra note 26, at 1034-1037. Consider, for example, the case of a railroad operating from a division point like Meadville, Pennsylvania. The runs from that point extend on the one side into New York and on the other into Ohio, while still others remain wholly within Pennsylvania. It may very possibly occur that men employed in the same class of work may be injured in the same manner and to the same degree, and yet, though neighbors in Meadville, receive varying amounts of compensation.

Mention may also be made of the possible amplification and perfection of efforts toward 
These difficulties may be eliminated by a federal act, assuring workers general, prompt, and precise protection against destroyed or diminished earning power. The advocacy of legislation other than of the type contemplated by the new bill rests at least in part, however, upon the fear that a federal compensation act might be unconstitutional if broad enough in its application to avoid the problems observed in the present Liability Act. That is, some doubt is expressed as to whether a federal statute can be made applicable no only to workers who are employed in interstate commerce, but to the much broader category of workers subject to the hazards of the transportation industry. ${ }^{37}$

\section{III}

In the quarter of a century that has elapsed since the Supreme Court declared unconstitutional the first Federal Employers' Liability Act,

accident prevention under a federal system. Accident prevention is generally recognized as one of the most valuable products of workmen's compensation laws, although some state commissions are less acute than others in grasping the opportunities. The laggard and backward states would not be in a position to affect a federal program. But $c f$. dissatisfaction on this score with the administration of the Longshoremen's Act. Cochrane, $A$ Halting Commission (1931) 21 ANr. LAB. LEG. REv. 399.

37. See, e.g., Albertsworth and Cilella, supra note 29, at 787. Schoene and Watson suggest in addition, supra note 14, at 423-424, that Crowell v. Benson, 285 U. S. 22 (1932), would prevent effective administration of a compensation act. They believe that the decision in that case, requiring a trial de novo of certain issues already decided by the administrative agency hearing the case, would destroy one of the chief advantages of a compensation law, i.e. expeditious disposition of claims. The fear would seem justified only if a new compensation act were to be as limited in its application as is the present Liability Act. The Supreme Court itself, in any event, has given some indication that Crowell $v$. Benson will not be wheeled into action except in most exceptional circumstances. See Voehl v. Indemnity Insurance Co. of North America, 288 U. S. 162 (1933); L'Hote v. Crowell, 286 U. S. 528 (1932). Moreover, examination of recent decisions in the lower Federal courts does not disclose that Crowell $v$. Benson has in fact played an obstructive role in the administration of the Longshoremen's and Harbor Workers' Act. See Ocean Steamship Co. v. Lawson, 68 F. (2d) 55 (C. C. A. 5th, 1933); Harris v. Hoage, 66 F. (2d) 801 (App. D. C. 1933); Liberty Mutual Insurance Co. v. Hoage, 65 F. (2d) 822 (App. D. C. 1933); Texas Employers' Insurance Association v. Sheppeard, 62 F. (2d) 122 (C. C. A. 5th, 1932) ; Todd Dry Docks, Inc. v. Marshall, 61 F. (2d) 671 C. A. 1st, 1932) ; Baltimore \& Ohio Rr. Co. v. Parker, 4 F. Supp. 815 (D. Md. 1933); C. A. 9th, 1932) ; Powell v. Hoage, 57 F. (2d) 766 (App. D. C. 1932); Bethlehem Shipbuilding Corp. v. Monahan, 57 F. (2d) 217 (D. Mass. 1932), aff'd, 62 F. (2d) 299 (C. C. A. 1st, 1932) ; Baltimore \& Ohio Rr. Co. v. Parker, 4 F. Supp. 815 (D. Md. 1933); Employers' Liability Association Corp. v. Hoage, 67 F. (2d) 227 (App. D. C. 1934). Cf. Baltimore \& Ohio Rr. Co. v. Clark, 59 F. (2d) 595 (C. C. A. 4th, 1932); Continental Casualty Co. v. Lawson, 2 F. Supp. 459 (S. D. Fla. 1932), rev'd, 64 F. (2d) 802 (C. C. A. 5th, 1933). See Note (1934) 43 YaLE L. J. 640, 645. See also Note (1933) 46 Harv. L. REV. 478; Note (1932) 30 MICH. L. REV. 1312. 
the trend of legislation has been definitely toward centralization of functions in the federal government. The decisions of the Supreme Court have kept pace with this legislative recognition of governmental exigencies. With the exception of its refusal to sanction congressional control of the shipment of goods made in factories employing children, the Court has been constant in its approval of statutes passed in the exercise of the power to regulate commerce among the states.

A concomitant of the development of federal control has been an awakened recognition of the fact that characteristically intrastate matters may fall within the ambit of congressional power. No new principle was involved, for it has long been agreed that Congress is authorized to enact whatever legislation is appropriate to protect or promote interstate commerce and the instrumentalities by which it is carried on..$^{33}$ There has seemed to be, however, a more acute realization of the nexus between state and federal concerns. Wherever the relationship of matters of intrastate commerce and interstate commerce has been thought to be so close as to affect the latter, federal control of the former has been sanctioned. The rate cases are familiar examples. $^{39}$ Similarly, the Supreme Court has approved of federal orders regarding abandonment or maintenance of railroad branch lines lying wholly within one state $;^{40}$ a federal statute regulating a local board of trade dealing in grain futures; ${ }^{41}$ a federal penalty for disposing of stolen automobiles; ${ }^{42}$ and the restraining of intrastate activities which affect the flow of interstate commerce. ${ }^{43}$

In the realm of transportation employment, Congress has been held competent to establish safety-appliance regulations applicable both to interstate and intrastate traffic ${ }^{44}$ to prescribe rules of liability to workers injured by reason of defective or prohibited equipment on either inter-

38. See Mobile County v. Kimball, 102 U. S. 691, 697 (1881); The Daniel Ball, 10 Wall. 557, 564 (U. S. 1871).

39. See Houston, E. \& W. T. Ry. Co. v. United States, 234 U. S. 342 (1914); Railroad Commission of Wisconsin v. Chicago, B. \& Q. Rr. Co., 257 U. S. 563 (1922); New York v. United States, 257 U. S. 591 (1922); Louisiana v. United States, 284 U. S. 125 (1931). And see United States v. Louisiana, 290 U. S. 70 (1933).

40. See Transit Commission v. United States, 284 U. S. 360 (1932); Colorado v. United States, 271 U. S. 153 (1926) ; cf. Texas v. Eastern Texas Rr. Co., 258 U. S. 204 (1922).

41. Chicago Board of Trade v. Olsen, 262 U. S. 1 (1923); and see Stafford v. Wallace, 258 U. S. 495 (1922); United States v. Ferger, 250 U. S. 199 (1919).

42. See Brooks v. United States, 267 U. S. 432 (1925); and cf. Hipolite Egg Co. v. United States, 220 U. S. 45 (1911).

43. See Local 167, International Brotherhood of Teamsters v. United States, 54 Sup. Ct. 396 (1934). And see Bedford Cut Stone Co. v. Stone Cutters' Association, 274 U. S. 37, 46-47 (1927) ; Northern Securities Co. v. United States, 193 U. S. 197 (1904).

44. See Southern Railway v. United States, 222 U. S. 20 (1911). 
state or intrastate trains $;^{45}$ and to provide for the safety of employees by limitations of the hours of service in either class of commerce.40 Its power to regulate the wages of all railroad employees, to prohibit railroads from influencing the selection of employee representatives under the Railway Labor Act, and to insist upon appropriate ashpans and safe boilers on locomotives, has not been questioned on the score that the exercise of the power extended in some measure to intrastate matters. ${ }^{47}$

The question in each case is one of fact. Is the regulation of intrastate commerce required to further and perfect the regulation of interstate commerce $?^{48}$ The Safety Appliances Act was upheld as to intrastate cars because the activities of the transportation business made it clear that the security of interstate commerce could not be advanced unless all rolling stock carried uniform approved equipment. The Hours of Labor Act was approved because excessive hours in intrastate activity would destroy the beneficent and protective purpose of restricting the hours of occupation in interstate commerce. Similarly, when wage-regulation was shown to be required in an emergency, the interrelationship of all types of railroad employment was so clear as to preclude the possibility of assuring continuity of service by only a partial regulation. Indeed, Mr. Justice Van Devanter, writing for the Court in the Second Employers' Liability Cases ${ }^{49}$ and again in Illinois Central Railroad Co. v. Behrens, ${ }^{50}$ has indicated that the present

45. Texas and Pacific Ry. Co. v. Rigsby, 241 U. S. 33 (1916); see also Ward v. Erie Rr. Co., 230 N. Y. 230, 129 N. E. 886 (1921), cert. dent., 256 U. S. 696 (1921).

46. Baltimore \& Ohio Rr. Co. v. Interstate Commerce Commission, 221 U. S. 612 (1911).

47. See Wilson v. New, 243 U. S. 332 (1917); Texas \& New Orleans Rr. Co. v. Brotherhood of Railway and Steamship Clerks, 281 U. S. 548 (1930); Ash Pan Act of May 30, 1908, c. 225, 35 STAT. 476 (1908), 45 U. S. C. \$\$ 17-21 (1926); Boiler Inspection Act of Feb. 17, 1911, c. 103, 36 STAT. 913 (1911), 45 U. S. C. \$\$ 22-34 (1926), as frequently amended; Great Northern Ry. Co. v. Donaldson, 246 U. S. 121 (1918); Baltimore \& Ohio Rr. Co. v. Groeger, 266 U. S. 521 (1925); see especially Napier v. Atlantic Coast Line Rr. Co., 272 U. S. 605 (1926). And see Hassenauer, Congressional Legislation Affecting Railroad Employees (1933) 8 Notre Darre LAw. 429.

48. Declarations and findings by Congress are of great weight in inducing the Court to approve an affirmative answer to that question. See Chicago Board of Trade v. Olsen, supra note 41. And it may be noted here that the burden of proof would seem to be on the party seeking to show that the answer should be negative. See Stafford v. Wallace, supra note 41 , at 521 : ". . . it is primarily for Congress to consider and decide the fact of the danger and meet it. This court will certainly not substitute its judgment for that of Congress in such a matter unless the relation of the subject to interstate commerce and its effect upon it are clearly nonexistent." Cf. Florida v. United States, 282 U. S. 194 (1931).

49. 223 U. S. 1,48 (1912).

50. 233 U. S. 473,477 (1914). And see the opinion of Chief Judge Cardozo in Carey v. New York Central Rr. Co., 250 N. Y. 345, 355, 165 N. E. 805, 808 (1929). 
Federal Employers' Liability Act is unnecessarily restricted in its application only to those employees whose service at the time of injury was in interstate commerce. A railway, he observed, is a highway for both types of commerce, interdependent as to safety and movement, and there is great practical difficulty in separating the general work of train crews into one compartment or the other; hence, Congress might have chosen to have regard for the general character of the employee's work, rather than for the precise nature of his occupation at the moment of misfortune. This suggestion is but further recognition of the rule that Congress may in its discretion legislate to whatever extent is necessary to make effective its control over interstate commerce.

The decisions under the Federal Employers' Liability Act themselves demonstrate the link that binds to interstate commerce the employees of the categories enumerated in the proposed bill. Their work is interchangeably in the two classes of commerce; their functions, whether wholly within one state ${ }^{51}$ or in several, are precedent conditions to the flow of goods and passengers. They are of a class especially trained for the tasks performed; the workers in the repair shop, the watchmen, the yard clerks, and all the other groups constitute a pool of labor from which are drawn the momentary needs of interstate commerce. Whatever affects the personnel or efficiency of that pool ${ }^{52}$ is within the power

51. The Wagner Bill does not purport to embrace within its terms employees of a company who are engaged in some local activity not intimately related to the movement of commerce. Cf. Delaware, L. \& W. Ry. Co. v. Yurkonis, 238 U. S. 439 (1915), where a miner employed in a coal mine owned by the railroad, suing to recover for injuries received in an explosion in the mine, was held not to be engaged in interstate commerce, although the coal might be used in the conduct of interstate commerce after it was mined. Nor does the bill cover resident office or building employees, whose accident hazards are not of a kind special to the transportation industry and who may readily be made compensable under state laws for such injuries as they may suffer in the course of their employment. The accident reports show that members of this class, though numerous, suffer casualties with relative infrequency. Accident Bull. No. 101 (I. C. C., Bur. of Statistics, 1933) 16. A section of the new bill provides that "Nothing in this act shall be construed as restricting in any way the application to employers subject to this act of the laws of any state providing rules of liability or compensation for disability or death suffered by employees not covered by the provisions of this act." The section should foreclose any contention that Congress, by legislating as to some employees and not others, intended "to occupy the whole field." Cf. Oregon-Washington Rr. \& Navigation Co. v. Washington, 270 U. S. 87 (1926); and see the Act of April 13, 1926, 44 Stat. 250 (1926), 7 U. S. C. SUPp. VII $§ 161$ (1933), which was passed to overcome the effect of that decision.

52. It may be estimated that in the past winter, a period of less than customary employment, over one million persons were employed by the railroads, Pullman Company, dining car companies, and express companies in some aspect of rail transportation service or in the maintenance of way, structures, equipment, and stores. See Wage Statrstrcs of Class I Steasi Raitways in the United States, Dec. 1933 (I. C. C., Bur. of Statistics, 
of Congress to govern. Even those employees of the named categories who might never be engaged, as the Court has defined the term, in interstate commerce or in work so closely related thereto as to be a part of it, are appropriate objects of federal concern, for upon their continued service rests much of the burden of keeping open the highways of travel and of maintaining and protecting the equipment to be used on those highways. ${ }^{53}$ In truth, the coverage of the Wagner Bill is but an adaptation of the suggestion contained in Illinois Central Rail-

1934); I. C. C. Release, March 6, 1934; Prelumtanary Abstract of Statistics of Comiaron Carrters for 1932 (I. C. C., Bur. of Statistics, 1933) 31, 33; Statistics of RaIlways IN THE UNITEd States for 1931 (I. C. C., Bur. of Statistics, 1932) S-17, S-19. Employees of Pullman or express companies are not covered by the present Liability Act. See Robinson v. Baltimore \& Ohio Rr. Co., 237 U. S. 84 (1915) ; Wells, Fargo \& Co. v. Taylor, 254 U. S. 175 (1920). During the ten year period, January 1, 1923 to December 31, 1932, the numbers of railroad employees (exclusive of Pullman, express company, and like employees) killed and injured in each year were as follows:

$\begin{array}{ccc}\text { Year ended } & \text { Killed } & \text { Injured } \\ \text { Dec. 31, 1923 } & 2,026 & 152,678 \\ \text { Dec. 31, 1924 } & 1,543 & 125,319 \\ \text { Dec. 31, 1925 } & 1,599 & 119,224 \\ \text { Dec. 31, 1926 } & 1,672 & 111,903 \\ \text { Dec. 31, 1927 } & 1,570 & 88,223 \\ \text { Dec. 31, 1928 } & 1,329 & 70,873 \\ \text { Dec. 31, 1929 } & 1,428 & 60,739 \\ \text { Dec. 31, 1930 } & 977 & 35,872 \\ \text { Dec. 31, 1931 } & 677 & 23,358 \\ \text { Dec. 31, 1932 } & 579 & 17,742\end{array}$

Accident Bull. No. 101, supra note 51, at 81 . The figures do not cover all accidents resulting in injury to an employe. Id. at 86 . The decline in casualties may be attributed in part to reduction in volume of business handled. For example, the tons of freight originated by Class I railways dropped 22.46 per cent between 1930 and 1931, while there has been a marked, though not altogether steady, decrease in the number of tons carried annually during the period 1923-1931. See Statistics of Rarlways IN THE UNITED STates FOR 1931, op. cit. supra, S-40, S-41. This factor does not, however, account for the whole decline. In 1923, the number of employees in service per employee injured was only twelve; in 1932 the number had risen to sixty. Accident Bull. No. 101, supra note 51, at 81. The number of trainmen in service per trainman injured was even smaller, being ten in 1923 and thirty-one in 1932. Ibid.

53. See cases cited in notes 44, 45, and 46, supra. Extended citation of cases showing the nexus between intrastate employments and the needs of interstate commerce is deemed unnecessary. Reference may be made to the discussion in Schoene and Watson, supra note 14. One of many examples is Erie Rr. Co. v. Welsh, 242 U. S. 303 (1916), where an employee was injured en route to the yardmaster's office; if he had arrived safely, he would have been given orders to make up an interstate train. Similarly, in Minneapolis \& St. Louis Rr. Co. v. Winters, 242 U. S. 353 (1917), an engine repairman was incapacitated from serving the needs of interstate locomotives. In Chicago \& Eastern Illinois Rr. Co. v. Industrial Commission, supra note 23 , the injured employee's work affected the supplying to interstate locomotives of the fuel without which they could not move. 
road Co. v. Behrens; ${ }^{54}$ it goes further only in that it establishes a general definition, operative regardless of the particular facts of the individual case. In view of the administrative difficulties and the cost of determining in each instance whether a man's past or future services might play a part in interstate commerce, and of the desirability of a speedy, almost automatic settlement of claims for injuries, ${ }^{55}$ it would seem clear that occasional anomalies should not invalidate the proposed scheme. What may be characterized as the "rule of administrative necessity" is well established by the Supreme Court's decisions. ${ }^{56}$

It may be conceded that the view here urged would necessitate at least a substantial departure from the First Employers' Liability Cases, though clearly the Wagner proposal is not so broad as the Act there condemned. But it must be recalled that the approach of the Court in the earlier case was not a factual one, nor was such an approach urged upon it. The difficulties illustrated by the operation of the present Act were not then appreciated. A change of result, it is now recognized, is required by expanded knowledge of the facts upon which a statute must operate. ${ }^{.7}$

\section{IV}

What has been said as to railroads and their satellite agencies would seem equally applicable to the other types of transportation activity included in the Wagner Bill. The carriers enumerated in Section 2(3) are, save for the water carriers which may better be dealt with in a statute limited to maritime concerns, the chief commercial competitors of the railroads. The whole trend of government regulation is toward co-

54. Supra note 50 .

55. Representatives of the carriers, appearing before the Sutherland Commission long before the abundant flowering of perplexities under the Federal Employers' Liability Act, recognized the necessity and desirability of extending the proposed compensation act to others than "interstate" employees. See, e.g., Hearings, supra note 26, at 1043, 1038-1039, 1020-1021.

56. See, e.g., Powell v. Pennsylvania, 127 U. S. 678 (1888); Purity Extract \& Tonic Co. v. Lynch, 226 U. S. 192 (1912); Jacob Ruppert v. Caffey, 251 U. S. 264 (1920); Euclid v. Ambler Realty Co., 272 U. S. 365 (1926); Milliken v. United States, 283 U. S. 15 (1931). Cf. Hoeper v. Tar Commission, 284 U. S. 206 (1931); Heiner v. Donnan, 285 U. S. 312 (1932).

57. See Abie State Bank v. Bryan, 282 U. S. 765 (1931); (1931) 40 YALE L. J. 1101; People v. Charles Schweinler Press, 214 N. Y. 395, 108 N. E. 639 (1915) ; and see Note (1933) 42 Yale L. J. 1250. The Supreme Court has reversed itself frequently when further consideration cast doubt on previous rulings. See the dissenting opinion of Mr. Justice Brandeis in Burnet v. Coronado Oil \& Gas Co., 285 U. S. 393, 405 (1932); Sharp, Movement in Supreme Court Adjudication-A Study of Madified and Overruled Decisions (1933) 46 HaRv. L. REv. 361, 593, 795. 
ordination of the transportation facilities of the country, 58 and the present proposal is conformable with that tendency.

The interstate movement of goods and passengers by truck and bus is increasingly important, ${ }^{59}$ and presents numerous problems resembling or affecting those noted in rail transport. The proposed bill, contemplating the administrative difficulties involved, as well as the hardship imposed on those who, because of sporadic and unexpected engagements in interstate commerce, might be compelled to insure under both state and federal acts, is limited to common or contract ${ }^{60}$ carriers operating between fixed termini or on a regular schedule or route. ${ }^{61}$ Motor transport of this type is marked by peculiar hazards, arising, for example, from efforts to maintain schedules en route on crowded highways, from bad employment conditions and overly long hours of service, from use of vehicles not adapted to the purpose for which they are used, and from the frequent transportation of explosives and inflammable liquids. ${ }^{62}$ The largely interstate character of many of the operations vitiates effective state regulation. $^{63}$ Financial irresponsibility is especially marked among

58. See, e.g., Report of the I. C. C. on Coordination of Motor Transport, 182 I. C. C. 263 (1932) ; Report of the Federal Coordinator of Transportation on Regulation of Transportation Agencies, SEN. Doc. No. 152, 73d Cong., 2d sess. (1934).

59. The I. C. C. Report, supra note 58, shows that in 1929 the volume of trucking in ton miles was six per cent of rail traffic and four per cent of all inland traffic; the percentages are thought to be higher at present. Id. at 274-275, Appendix B, at 400-407. Five per cent of all trucking is by common carriers in interstate commerce, and seven and a half per cent by contract carriers in interstate commerce. Id. at 274-275. Intercity bus traffic, of which in 1930 about twenty-five per cent was interstate, accounted for the movement of over seventy per cent as many passengers as the railroads, though for a shorter average distance. Id. at $277,278,377,379$. Steam and electric railroads, through subsidiaries or affiliates, operate motor carriers as substitutes for or supplements to train service, or entirely independently of rail operations. Id. at $319,345,348$ et seq. Appendix A, at $395,400$.

60. There would seem to be no constitutional difficulty, other than that discussed in this paper, involved in this type of regulation of contract carriers. Cf. Brown and Scott, Regulation of thie Contract Motor Carrier under the Constitution (1931) 44 HaRv. L. Rev. 530, 566; Rosenbaum and Lilienthal, Motor Carrier Regulation: Federal, State and Municipal (1926) 26 Cor. L. REv. 954.

61. Report of I. C. C., supra note 58, Appendix F, at $410-413$, contains a summary of state regulations of common and contract carriers by motor vehicle; the existing state findings may be useful in determining in each given case whether a particular carrier is operating on a regular route or schedule.

62. Id. at $282,295,296,298,356,370,371$.

63. Id. at 371 . The author is privileged to quote the following from a letter addressed to him on April 10, 1934, by Mr. V. A. Zimmer, Director of the Division of Worlmen's Compensation of the New York Department of Labor:

"An employer corporation domiciled in New Jersey operates a fleet of trucks in New Jersey, Pennsylvania and New York engaged in gathering milk and bringing it to a receiving station in Brooklyn. The employer recognizing his responsibility for compensation coverage instructed his broker to secure a policy. It developed however, that the New Jersey 
the interstate operators, who are less subject to state supervision; ${ }^{64}$ typically, both truck and bus companies are small units. ${ }^{65}$ Yet these operations have a serious effect not only upon the operating and financial problems of railroads, ${ }^{66}$ but also upon wages and conditions of employment for rail workers. ${ }^{67}$ The Interstate Commerce Commission suggests the desirability of uniform regulation by Congress to assure safety and convenience in the motor transport field. ${ }^{6 s}$

Aircraft transportation is not at present of prime importance in the national economy, though it may be expected to be of increasing sig-

carriers declined the risk because of uncertainty of the extra territorial liability. Thereupon the broker applied to the New York State Insurance Fund. The management however, expressed the opinion that there was probably no liability existing for New York State coverage and therefore declined to issue a policy unless this Department or the Department of Law would supply an opinion that New York State liability was indicated.

"The practical difficulty about this procedure is the fact that neither the Industrial Commissioner nor the Department of Law can properly undertake to give a coverage opinion as to the coverage obligation of a private employer for two reasons. First, because such opinion would not be binding upon the Industrial Board or the courts in any actual case later presented and further because a slight variation in the facts would render such opinion inapplicable. Hence all that this Department can tell the broker in this dilemma is that we would not attempt to enforce coverage under the mandatory provision of our Act because in any criminal prosecution for failure to provide coverage we would not be in a position to prove to the satisfaction of the court that coverage responsibility clearly exists.

"Despite the fact that the higher courts of this state have passed upon a number of cases involving coverage obligation of employers engaged in interstate commerce, the truth is that there still exists great uncertainty as to what the ruling would be in any given set of facts such as set forth by this broker. . .

"As the broker points out, even if the employer secures Jersey coverage it may well be that an employee who happens to be injured in New York State may file a claim under our Act because of the more liberal benefits prevailing under our statute. The insurance carrier would, of course, resist the claim because he has received a premium based upon the New Jersey Act and experience and it might well be that if the courts sustained the claim the employer might be held liable and his New Jersey carrier released. In this event the employer would be a non insurer and therefore subject to a penalty for a misdemeanor as well as burdened with the liability for payment of the award. To be entirely on the safe side it would seem that such an employer would be forced to take coverage in all three states. This involves an extraordinary and unwarranted expense to say nothing of the complications involved in establishing a separate payroll as a basis of premium for each of the several carriers. ...

"It seems to me that this case illustrates the desirability of a Federal statute bringing all interstate commerce carriers within its scope not only to avoid the delay in adjudication in actual accident or death cases presented, but to eliminate the uncertainty as to coverage responsibility on the part of employers engaged in this enterprise."

64. Report of I. C. C., supra note 58, at 280.

65. Id. at 276,279 .

66. Id. at 294,320 et seq.

67. Id. at 383 .

68. Ibid. 
nificance. ${ }^{69}$ The present protection afforded by the States to aviation workers is said to be unsatisfactory, though burdensome upon the industry. ${ }^{70}$ Pipe lines carry an important share of all inland traffic ${ }^{71}$ and those who are employed in the industry, though it may be assumed that their actual work is consistently localized, must regularly be occupied interchangeably in interstate and intrastate commerce. ${ }^{72}$

Adequate safeguards for employees in these several interstate transportation activities are difficult of achievement in the absence of federal action. Analogous experience need not be ignored by the legislature in developing a statutory program. The strategic value of a single program, covering all competing interests, is obvious; it should not be sacrificed in favor of piecemeal treatment of the problem.

\section{ConCLUSION}

The present state of legislation is unsatisfactory. Amendment of the existing scheme, while curative of some glaring defects, would not serve to further the modern social policy regarding compensation for industrial injuries. The Federal Employers' Liability Act, however much refurbished, would continue to condition redress upon the employer's fault, rather than upon the fact of loss to the worker and the community. Application to interstate transportation of local workmen's compensation acts, on the other hand, seems presently undesirable because of disparity among the various state laws and because of the probable high cost of securing insurance coverage.

An immediately effective system is at hand, however, in the scheme for an inclusive federal act. Rigid distinctions between interstate and

69. See Strong, Recent Changes in American Transportation and the Future of Transport by Air (1931) 7 DeL. Notes 79, especially at 88-96.

70. See Pillsbury, Application of Federal Compensation Acts to Aviation (1933) 4 ATR L. Rev. 38, 45. The classifications of employments in the aviation industry are generally analogous to those in the rail transport industry, and the interrelationship of inter- and intrastate activities is of the same character. Id. at 43-45, and see id. at 39-40. The licensing of pilots and planes is in fact almost wholly in the hands of the federal government today, because of the circumstance that aircraft operations are rarely carried on solely within one state. See MIILER, INLAND TRANSPORTaTion (1933) 713-715.

71. The percentage was estimated to be 5.2 in 1929. Report of the I. C. C., supra note 58, at 403. And see MIILER, op. cit. supra note 70, at 737-745.

72. Eureka Pipe Line Co. v. Hallanan, 257 U. S. 265 (1921); United Fuel Gas Co. v. Hallanan, 257 U. S. 277 (1921); State Tax Commission v. Interstate Natural Gas Co., 284 U. S. 41 (1931), show the practical difficulty of isolating the intrastate portion of pipe line contents, even when the lines are mere "gatherers" within a state. Cf. Atlantic Coast Line Ry. Co. v. Standard Oil Co., 275 U. S. 257 (1927). The same difficulty, it may be expected, would attach to determining whether at any given time (such as the time of injury) one who was occupied in maintaining or operating pipeline facilities was or was not employed in interstate commerce. 
intrastate commerce must give way before compelling practical considerations. The distressing results of the present law are apparent. A court will hesitate long before it denounces as unwarranted a legislative conclusion that a workmen's compensation law like that to be proposed by Senator Wagner has no relation to the safety of goods and persons carried in interstate transportation or to the safety of the employees $^{73}$ who are indispensable, as a body, to that transportation.

73. A workmen's compensation act might well stimulate greater accident-prevention efforts, especially in connection with the construction or maintenance of way, structures, and rolling stock, where the influence of safety legislation is less directly felt than in the actual operation of trains. "Nontrain accidents" furnish a very large percentage of annual railroad casualties reported to the Interstate Commerce Commission. See Accident Bull. No. 98 (I. C. C., Bur. of Statistics, 1930) 69; Id. No. 99 (1931) 65; Id. No. 100 (1932) 65; Id. No. 101 (1933) 46; and see LaUCK, Occupation HazaRd of UNskILLED Exrployees oN THE RAIrRoads (1921). A connection between the safety of employees and the safety of passengers is suggested by the rough correspondence between the fiuctuations in the figures of those killed or injured in the two groups. See Accident Bull. No. 101, supra note 51, at 81 , Statement No. 1. 